\title{
Applications of Information Communication Technology (ICT) in Academic Libraries: An Overview of Turkana University College Library
}

\author{
Jeremiah Osida Onunga \\ Turkana University College, Lodwar, KENYA \\ Department of Renewable Energy \& Technology
}

Received: 2 August 2021 - Accepted: 1 October 2021 - Published Online: 27 October 2021

\begin{abstract}
Information is considered as need of human in the recent undertakings. In this paper the study has been done to research on application of Information communication Technology (ICT) and uses of ICT tools in Academic Libraries, with a focus on Turkana University College Library, to find out the application of ICT skills in Library Information Science professionals and to modernize the libraries. The study has been done in the School of Science and Technology and School of Education and Social Sciences, with the aims: (1) how students in these schools apply ICT in the library, and (2) how ICT tools are applied to provide innovative services to the users. This paper shows that the application of ICT tools is increasing in academic libraries especially from the two schools of Turkana University College, due to the development of technologies and according to the respondent ranking mobile phone is making it inevitable, due to easy access at any time anywhere.
\end{abstract}

Keywords: Library Information Science, application of ICT, academic libraries, ICT tools.

\section{Introduction}

Information is the key factor in any kind of research and development. The information itself and the way it is accessed have undergone changes owing to the development in information and communication technology. According to information it is considered as a fifth need of human beings after ranking air, water, food and shelter. Information technology entered into libraries, especially academic libraries and research libraries during 1960s. Quick and easy access to every required information is a supreme importance especially in academic libraries. Information processing, storage, communication, dissemination of information automation, further origin of Internet and development of World Wide Web, have revolutionized the information communication technology. Based on this, the application of ICT in libraries become essential to provide the facilities of the user community. Ebijuwa (2005) and ToAnyakoha (2005) define ICT as "tools and as well as means used for collection, capture, process, storage, transmission and dissemination of information." The American Library Association (1983) defines IT as "the application of computers and other technologies to the acquisition, organization, storage, retrieval and dissemination of information." The computers used to process and store data, while telecommunications technology provides information communication tools, which make it possible for users to access databases and link them with other computer networks at

(C) Authors. Terms and conditions of Creative Commons Attribution 4.0 International (CC BY 4.0) apply. Correspondence: Jeremiah Osida Onunga (Tutorial Fellow), Turkana University College, Department of Renewable Energy \& Technology, Lodwar, KENYA. E-mail: jerryosida@gmail.com. 
different locations. IT and ICT (Information and Communication Technologies) are used somewhat interchangeably.

The study reveals the drawbacks of the information access through print media. It elucidates the wide growing gap in volume of consumption between print media and electronic media by students of Turkana University College. The study is confined to the impact of ICT information on the access pattern of students studying at Turkana University College. The main aim of the study is to measure the respondents' ICT information needs and their information seeking behavior in collecting ICT resources. Further, their attitudes towards ICT information are also measured. It also proves how far ICT information make impact on the access pattern among the users of both professional and non-professional and the extent of ICT information being increasingly used rather than print resources. In the information communication technological world, knowing the respondents' changing attitude towards ICT information is very essential. In this context the study is needed in the present scenario.

\section{Literature review}

Walmiki and Ramakrishnegowda (2009) studied ICT infrastructure in university libraries and found that most of the libraries "lack sufficient hardware, software facilities and do not have adequate internet nodes and bandwidth." The campus LANs were not fully extended to exploit the benefits of digital information environment. Ahmad and Fatima (2009) found that researchers use a variety of ICT products and services for research and further remarked that ICT products help "to find information, access information more easily." It was recommended that training can be organized to increase the use of ICT-based products and services. Shafi-Ullah and Roberts (2010) found that ICT infrastructure lacked funding and recommended allocating funds for ICT infrastructure. K. S. Sivakumaren, Dr V Geetha and B. Jeyaprakash (2011) stated that the university libraries must increase the numbers of computer available to enable the users to maximize the usage of ICT-based resources and services and it is found that most libraries have not implemented digitization of library management software. It is very useful to digitize rare collections such as older and out of print editions. Mhammed Ijas Mairaj, Widad Mustafa EI-Hadi (2012) found that provision of hardware, standardized library software, adequate financial resources, and proper training facilities for medical libraries will help to strengthen ICT applications in medical libraries.

\section{Applications of ICT in academic libraries}

Nowadays there are several information communication technologies for various housekeeping, management and administrative functions of the library, different electronic and digital media, and computer aided electronic equipment, networks and Internet has provided significant role in retrieval and dissemination of information and playing a vital role for modernization of libraries.

\subsection{Library management}

Library management includes the following activities which will certainly be geared up by the use of these fast ICT developments: classification, cataloging, indexing, database creation, and database indexing. 


\subsection{Digital library}

A digital library is an assembled of digital computing, storage and communication machinery together with the content and software needed to reproduce, emulate and extend the services provided by conventional libraries based on paper and other material means of colleting, cataloging, finding and disseminating information. A full-service digital library must accomplish all essential services of traditional libraries and also exploit the well-known advantage of digital storage, searching and communication. It provides access to part of or all its collection, such as plain texts, images, graphics, audio and video materials and other library items that have been electronically converted, via the Internet and www.

\subsection{Library automation}

Library automation is the concept of reducing the human intervention in all the library services so that any user can receive the desired information with the maximum comfort and at the lowest cost. Major areas of the automation can be classified into two-organization of all library database and all housekeeping operations of library.

\subsection{Library networking}

Library networking means a group of libraries and information centers are interconnected for some common pattern or design for information exchange and communication with a view to improve efficiency.

\subsection{ICT-based user services}

Some library users are adopting electronic habits, making increasing use of the new ICT including computers, the Internet, the Web, Intranet, Extranet and other technologies. As a result, library users are placing new demands on their libraries. They require access to the latest information, updated information resources and access to ICT facilities that they could use in their work. Use of ICT in libraries enhances user satisfaction. It provides numerous benefits to library users. Some of the benefits are:

- Provide speedy and easy access to information;

- Provides remote access to users;

- Provides round the clock access to users;

- Provides access to unlimited information from different sources;

- Provides information flexibility to be used by any individual according to his/her requirements provides increased flexibility;

- Facilitates the reformatting and combining of data from different sources.

following:

Libraries are also providing various ICT-based services to their user, including the

- Provision of Web access to OPACs;

- Electronic document delivery;

- Networked information resources;

- Delivery of information to user desktops; 
- Online instructions;

- Online readers advisory services.

\section{Impact of ICT on libraries and librarians}

Computer has brought in a new impact to the library and information usage. In libraries, information technology has assisted library professionals to provide value added quality information service and give more remote access to the inter-nationally available information resources. Today's highly sophisticated information technology to facilitate the storage of huge amounts of data or information in a very compact space. Information technologies promise fast retrieval of stored information and revolutionize our concept of the functions of a traditional library and a modern information center. Recently technological developments have dramatically changed the mode of library operations and services. Modern ICT is impacting on various aspects of libraries and the information profession. Advancements in ICT and the wide spread use of ICT is resulting in digital information sources and digital media replacing and becoming the dominant form of information storage and retrieval. ICT also survives and makes true rules of Library Science "every reader his/her book/information," "save the time of the reader," "library is a growing organism." ICT with its tremendous information sources, rapid transmission speed and easy access ensures the satisfaction of the user with complex demand, break down the distance barrier and shortened the time required and ensure the right information to the right reader at the right time. It also increases and solves the library's demand of collection development. It is really an excellent tool for the library information centers.

\section{Components of ICT in libraries}

ICT came about as a result of the digital convergence of computer technologies, telecommunication technologies and other media communication technologies.

Components of Information Technology (IT), which are frequently used in library and information center are:

- Computer technology;

- Communication technology;

- Reprographic, micrographic and printing technology.

ICT is the fusion of two important technologies: electronic and communications.

\section{Methodology}

The study was based on the primary data collected from students from School of Science and Technology and School of Education and Social Sciences who frequently use the University College main library. A structured questionnaire was designed based on ICT applications. The questionnaire was divided into seven major applications of ICT tools (e-group, e-mail, fax, Internet, Intranet, mobile phone, video conference), and 175 questionnaires were distributed among students. The sample of 175 was informed from data that was collected from the libraries and targeted students who did their studies in the library for at least three days during that week and have been a student from either school. Both primary and secondary data were used for the present research. Primary data have been collected from the users of academic libraries (students from school of Arts and Social Sciences and Information Communication and Media 
Studies). The secondary data were collected from the web sites and prospectus of institutions, research journals, magazines, reports and conference proceedings.

\section{Data analysis}

The study was carried out in four libraries of Turkana University College (one main library and three Campus libraries) the information to these respondents is shown in Table 1.

Table 1. Information about respondents

\begin{tabular}{|c|l|c|c|}
\hline S. No. & Description & Total (students) & Percentage \\
\hline $\mathbf{1}$ & Main Library (1) & 105 & $60 \%$ \\
\hline $\mathbf{2}$ & Campus Libraries (3) & 70 & $40 \%$ \\
\hline \multicolumn{2}{|c|}{ Total } & 175 & $100 \%$ \\
\hline
\end{tabular}

Seven major applications of ICT tools, such as e-group, e-mail, fax, Internet, Intranet, mobile phone, video conference, were identified for this study and same is shown in Table 2.

The table and the figure show all the respondent uses all the facilities but the highest is mobile phone with (90\%) and e-mail (89.09\%), Intranet (86.36\%) and Internet with (81.81\%). The use of mobile phones is high due to its fast and easy way of communication.

Table 2. ICT tools for academic libraries

\begin{tabular}{|c|l|c|c|c|}
\hline S1. No. & Name of ICT Tool & $\begin{array}{c}\text { No. of } \\
\text { users }\end{array}$ & $\begin{array}{c}\text { Respondent in } \\
\mathbf{\%}\end{array}$ & Rank \\
\hline $\mathbf{1}$ & e-Group & 86 & 78.18 & 5 \\
\hline $\mathbf{2}$ & e-Mail & 98 & 89.09 & 2 \\
\hline $\mathbf{3}$ & Fax & 40 & 36.36 & 6 \\
\hline $\mathbf{4}$ & Internet & 90 & 81.81 & 4 \\
\hline $\mathbf{5}$ & Intranet & 95 & 86.36 & 3 \\
\hline $\mathbf{6}$ & Mobile Phone & 99 & 90.00 & 1 \\
\hline $\mathbf{7}$ & Video Conference & 30 & 27.27 & 7 \\
\hline
\end{tabular}

Table 3. Use of ICT tools by gender

\begin{tabular}{|l|c|c|c|c|}
\hline \multicolumn{1}{|c|}{ ICT Media } & Male & Female & Total & Percentage (\%) \\
\hline e-Group & 30 & 28 & 58 & 52.72 \\
\hline e-Mail & 50 & 55 & 105 & 95.45 \\
\hline Fax & 20 & 20 & 40 & 36.36 \\
\hline Internet & 40 & 45 & 85 & 77.27 \\
\hline Intranet & 14 & 16 & 30 & 27.27 \\
\hline Mobile Phone & 53 & 55 & 108 & 98.18 \\
\hline Video Conference & 15 & 13 & 28 & 25.45 \\
\hline
\end{tabular}

Table 3 is a cross tabulation of ICT tools and gender and shows that female professionals are using mobile phones more than other media and female respondent use live video conference. 


\section{Conclusions and recommendations}

The application of ICT tools is increasing in academic libraries especially in Information Science and Arts, and Science Schools of Turkana University College due to the development of technologies. According to the respondents, mobile phone is ranked first due to easy access at any time anywhere. There is a lack of LAN facility in most of the academic libraries, Turkana University College Library has LAN facility at Main Campus library, so the usage of Internet is less which was shown in the Table 3. Turkana University College Library should increase the video conferencing facilities which enables the users to maximize the usage of ICT based activities and services. It has been observed that not many libraries are offering video conferences it is due to fewer consortiums. If consortium with other libraries will increase the usage of video conferencing will also increase.

\section{Acknowledgements}

This research did not receive any specific grant from funding agencies in the public commercial, or not-for-profit sectors.

The author declares no competing interests.

\section{References}

Ahmad, N., \& Fatima, N. (2009). Usage of ICT products and services for research in social sciences at Aligarh Muslim University. DESIDOC Journal of Library and Information Technology, 29(2), 25-30.

Cholin, V. S. (2005). Study of the application of information technology for effective access to resources in India in university libraries. The International Information \& Library Review, 37(2), 189-197.

Ebijuwa, A. A. (2005). Information and Communication Technology in university libraries: The Nigeria experience. Journal of Library and Information Science, 7(1\&2), 23-30.

Mairaj, M. I., Mustafa El-Hadi, W. (2012). Applications of Information and Communication Technologies in libraries in Pakistan. Journal of the Medical Library Association, 10o(3), 218-221.

... (n.d.). Is ICT Infrastructure capable to accommodate standardized library management systems? Case studies of library automation from public sector universities in Islamabad (Pakistan). Available at http://www.crl.edu.ac.in/icalo9/papers/indes_files/ical-44_191_402_1_RV.pdf.

Sivakumaren, K. S., Geetha, V., \& Jeyaprakash, B. (2011). ICT Facilities in university libraries: A study. Library philosophy and Practice (e-journal). Paper 628.

http://digitalcommons.unl.edu/libphilprac/628.

ToAnyakoha, M. W. (2005). Information and Communication Technology (ICT) in library services. Coal City Libraries, 2(1\&2), 2-12.

... (n.d.). Union catalog. http://en.wikipedia.org/wiki/Union catalog.

Walmiki, R. H., \& Ramakrishnegowda (2009). ICT infrastructure in university libraries of Karnataka. Annals of Library and Information Studies, 56, 236-241. 